\section{USA and poverty}

SIR-In his review of Asimov's book Past, Present, and Future (Nature 327, 667; 1987), Michael Spencer suggests that Asimov's view of the world population problem is naive.

In the course of his own brief observations on the subject he raises the related question of poverty in developing countries, asking: "Why are so many Third World countries unable to rise out of poverty? Could it be relevant that the United States has only a twentieth of the world's population but accounts for onethird of its consumption of resources?"

The implication is that the United States is somehow responsible for the poverty of developing countries. Let us explore this direction further. Let us suppose that an enormous politico-geological cataclysm were to submerge the United States beneath the sea and leave the rest of the world unscathed. How would this event affect the third world?

The tone of the review leaves little doubt that, freed from the shackles of US exploitation, the developing countries would rise out of poverty.

More probably the opposite would happen. In the absence of the greedy, spendthrift Americans, who had hitherto accounted "for one-third of [the world's] consumption of resources", demand for these resources would drop by one-third. World-market prices of raw materials and crops would collapse, a major source of sustenance for third world countries would be withdrawn and, far from rising out of poverty, they would sink into deeper poverty.

JOCELYN TOMKIN

Department of Astronomy,

University of Texas,

Austin, Texas 78712, USA

\section{What Fisher meant}

SIR - It is possible to demonstrate R.A. Fisher's support for almost any idea by changing what he wrote, and Sibly's attempt to adduce his posthumous support for "the optimization methods underpinning the modern evolutionary approach to biology" is breathtaking in its simplicity: just change genotype to gene in Chapter II of The Genetical Theory of Natural Selection ${ }^{2}$ because that is what "Fisher must have meant".

Taking such a liberty reveals a failure to understand The Fundamental Theorem of Natural Selection (the title of the chapter in question), whose point is precisely that in a diploid organism it is genotypes rather than genes that have to be considered. Fisher shows that the rate of increase in the mean fitness of a population is then equal to that component of the total variance which we nowadays call the additive genetic variance or the genic variance (a partitioning of the total variance which would be redundant if genes, and not genotypes, were being considered).

The theorem is, admittedly, not an easy one, and is frequently misunderstood. Thus Turner ${ }^{3}$ has recently misrepresented it as relying on "the reductionist assumption that the effects of all genes on the variance could simply be added, which is, in effect, the assumption that there is no interaction between genes, not even the interaction between alleles which we call 'dominance"'. Fisher made no such assumption (which, if made, would again be tantamount to dealing with genes and not genotypes); it is a consequence of the theorem that the dominance variance is not involved, not an assumption.

It sometimes seems as though "the modern evolutionary approach to biology" is so preoccupied with supposed maximization principles that in order to apply them it is prepared to omit some of the elementary facts of genetics, such as mating or dominance, as though Fisher had never written The Genetical Theory. The book quoted by Sibly ${ }^{4}$ is a good example, even Sewall Wright's idea of a "selective landscape" being misappropriated to describe a graph in which the independent variates are resources allocated to growth and to reproduction rather than the gene frequencies specified by Wright.

Biologists who import the theory of mathematical economics into evolutionary studies should at least avoid using the terminology invented by those who had supposed that the theory of mathematical genetics was more relevant, and they should resist absolutely the temptation to change words in quotations from the latter theory in order to match the preconceptions of the former.

A. W. F. EDWARDS Gonville and Caius College, Cambridge CB2 1TA, UK

1. Sibly, R.M. Nature 327, 268 (1987)

2. Fisher, R.A. The Genetical Theory of Natural Selection, $2 \mathrm{nd}$ edn (Dover, New York, 1958)

Turner, J.R.G. Oxford Surveys in Evolutionary Biology, 2. 159-96 (Oxford University Press, 1985)

4. Sibly, R.M. \& Calow, P. Physiological Ecology of Animals (Blackweil, Oxford, 1986)

\section{Investigating the paranormal}

SIR-Critics of my analysis of parascientific research ${ }^{1}$ provide no new arguments or evidence and the original conclusion of my Commentary - that parascience is pseudoscience - stands. If anything, the structure of their arguments strengthens this conclusion. Couch ${ }^{2}$ suggests that Bell's theorem provides a theory for psi phenomena but not a mechanism. Apart from the inconsistency of this argument, it remains doubtful whether Couch (or any- body else for that matter, including physicists) can actually demonstrate how Bell's theorem helps to explain psi phenomena. Couch asks whether millions of people are psychologically abnormal because Waugh's sample of believers had higher neuroticism scores than her sample of disbelievers. Of course not; having a significantly higher score does not imply abnormality but it does point to a trend.

Elitzur $^{3}$ claims that an empirical observation of personality differences between believers and sceptics is an ad hominem argument. If so, then a whole area of psychological investigation on personality differences must be similarly discredited. Elitzur's claim of misrepresentation should perhaps be answered by the two reviewers whose work I previously cited, Akers $^{4}$ and Hyman 5 .

Hyman's selection of experiments was actually provided by Honorton and included all ganzfeld experiments published up to the year 1984. The experiments conducted by $\mathrm{Jahn}^{6}$ and Krippner and Ullman ${ }^{7}$ which Elitzur cites as methodologically rigorous are themselves difficult to replicate and Elitzur's enthusiasm for this work may well prove to be misplaced.

Morris ${ }^{8}$ suggests that there is a corpus of paranormal research of which I am unaware which does not contain the flaws outlined in the Commentary, yet he fails to cite it. The reason is that this corpus of evidence does not exist. Such tireless faith in the paranormal hypothesis is hardly rational in the absence of any repeatable paranormal effect.

Stevenson's protestations ${ }^{9}$ may serve some therapeutic function, but like the other critics, he offers no new evidence of a repeatable experiment, only anecdote. Can science be based purely upon anecdote? Like Koestler and Rhine before him, Stevenson assumes that striking coincidences cannot occur by chance, a very serious error for a scientist in his field, as explained in my article. What parapsychologists need to do, if they wish to convince others that they have discovered something, is to produce some coherent theories and some convincing experimental demonstrations. Until then the sceptical majority can hardly be expected to take them seriously.

School of Psychology,

DAVID F. MARKS

Middlesex Polytechnic

Queensway,

Enfield EN3 4SF, UK

1. Marks, D.F. Nature 320, 119-224 (1986).

. Couch, M. Nature 321, 465 (1986).

. Elitzur, A.C. Nature 321, 465 (1986).

4. Akers, $\mathrm{C}$ in Advances in Parapsychological Research Vol 4

(ed. Krippner, S.) 112-164 (McFarland, Jefferson, North Carolina, 1984)

. Hyman, R. J. Parapsychol. 49, 3-49 (1985)

6. Jahn, R.G. Proc. IEEE 70/2, 136-170 (1982)

Krippner, S. \& Ullman, M.J. Am. J. Soc. psychosom. ment. Med. 20, 9-17 (1973).

Morris, R L Nature 322,680(1986)

9. Stevenson, I. Nature 322, 680 (1986). 